\title{
Galveno interešu centru noteikšanas un izvērtēšanas problemātika fizisko personu pārrobežu maksātnespējas procesos
}

\author{
Mg. iur. Inga Eglīte \\ Rìgas Stradiña universitāte, Juridisko zinātṇu \\ doktora studiju programma, Latvija \\ 027261@rsu.edu.lv \\ Prof. Osvalds Joksts \\ Rìgas Stradina universitāte, Juridiskā fakultāte, Latvija \\ osvalds.joksts@rsu.lv
}

\section{Kopsavilkums}

Rakstā tiek analizēts tas, cik dažādos veidos iespējams novērtēt un izpētīt, kur atrodas parādnieka galvenais interešu centrs, un kādiem apstākḷiem atklājoties var secināt pretējo - ka patiesais parādnieka galveno interešu centrs tomēr atrodas citā valstī, nevis Latvijā. Rakstā ir veikts parādnieku maldinošās informācijas apkopojums, kas var radīt maldinošu iespaidu tiesām galvenā interešu centra noteikšanai tieši Latvijā, kas l̦auj parādniekam fiziskai personai iziet atvieglotāku fiziskās personas maksātnespēju procedūru, salīdzinot ar to valsti, kurā ir parādnieka patiesais galvenais interešu centrs. Ir apkopota problemātika galvenā interešu centra noteikšanā un analizēti visbiežākie klupšanas akmeñi tiesu nolēmumos, uzsverot kopējas prakses ieviešanas nepieciešamību, lai neveidotos vai vismaz kḷutu retāki jauni līdzīga veida precedenti.

Atslēgvārdi: civilprocess, maksātnespējas process, fiziskās personas maksātnespēja, galvenais interešu centrs.

\section{levads}

Sākotnēji Maksātnespējas likuma izpratnē fiziskās personas maksātnespējas procedūras Latvijā realizēja tikai Latvijas pilsoṇi un nepilsoṇi, taču, laikam ejot, no kopējās statistikas arvien vairāk un vairāk redzams tas, ka citu ES valstu pilsoṇi vēlas realizēt fiziskās personas maksātnespējas procesu Latvijā. Šādos maksātnespējas procesos ḷoti svarīgi ir tas, kur atrodas fiziskās personas parādnieka galvenais interešu centrs. Par 
galveno interešu centru ir atrunāts gan Maksātnespējas likumā, gan Eiropas Parlamenta un Padomes Regulā Nr. 1346/2000, gan 2015. gada 20. maija Regulā (ES) 2015/848 par maksātnespējas procedūrām, taču galveno interešu centra noteikšanas problemātikai joprojām nav veltìta nepieciešamā uzmanība. Šajā pētỉjumā ir salīdzināti vairāku fizisko personu maksātnespējas procesi un apkopota informācija par problēmām un iespējamo problēmu atpazī̌anu pirms vai pèc tiesu nolēmuma pien,emšanas, lai tiktu pareizi interpretētas normatīvo aktu tiesību normas un likumdevēja griba. Tas viennozīmīgi atvieglos tiesu darbu un palīdzēs arī fiziskām personām labāk izprast to, kā pēc iespējas precīzāk var noteikt galveno interešu centru parādniekam.

Pētījuma rezultāti ir aprobēti Rīgas Stradiṇa universitātes organizētajā starptautiskajā zinātniski praktiskajā konferencē "Tiesiskās sistēmas aktuālās problēmas", kas notika 2020. gada 23. aprîlī tiešsaistē un kur tie tika prezentēti 2. sekcijā "Aktuālās problēmas tiesiskās sistēmas civiltiesību un krimināltiesību jomā".

Publikācijas mērḳis ir iepazīstināt, kādas nianses tiek un kādas netiek n,emtas vērā, lai noteiktu galveno interešu centru fiziskas personas maksātnespējas jomā, veicot tiesiskā regulējuma izpēti un tiesas nolēmumu analīzi, lai varētu šos procesuālos risinājumus izmantot Latvijas tiesu darba uzlabošanai un atvieglošanai. Pètijumā, izmantojot salīdzinošo, analītisko, aprakstošo, dedukcijas un indukcijas metodi, ir analizēti Latvijas un ārvalstu normatīvie akti.

\section{Fiziskas personas maksātnespējas procesa tiesību vispārīgs attīstības apraksts}

Maksātnespējas jēdziens ir pazīstams jau sen, un tas bija zināms jau Senajā Romā un senajās Austrumu zemēs, kopš atrodami pirmie pierādijjumi par tirdzniecības darbību; sākotnēji tas tika saukts par bankrotu jeb nespēju samaksāt parādus.

Romiešu krimināltiesībās ilgi saglabājās daudzas pirmatnējās kopienas iekārtas paražas. Tā maksātnespējīgo parādnieku līdz parādjūga atcelšanai (326. g. pirms m. è.) varēja vai nu pārdot verdzībā, vai nogalināt. Bet, ja bija vairāki kreditori, tad XII tabulu likumi aṭ̣âva parādnieku sacirst gabalos un atdot katram kreditoram pa gabalam. Maksātnespējas tiesību vēsture liecina, ka kārtīgai parādu atmaksai senajās tiesībās izmantoja arī citus visprimitīvākos draudus: likt parādnieku pērt uz laukuma, prasīt atmaksāt divkāršu parāda summu utt. [1].

Šobrīd process, neapšaubāmi, ir mainījies - tas ir kḷuvis civilizētāks. Lielāku nozīmi ir ieguvis parādnieka maksātspējas atjaunošanas mērkis, dodot iespēju parādniekam atgriezties civiltiesiskajā apritē. Šì mērḳa sasniegšanai lielāks uzsvars ir uz parādnieka atbrīvošanu no atbildības par atlikušajām neizpildītajām saistībām un iespēju pašam parādniekam lūgt sākt maksātnespējas procesu.

Mūsdienās jebkurš likums ir mērḳtiecīgas likumdevēja darbības rezultāts. Tādēl ir svarīgi, lai jebkuram likumam, to pien,emot, būtu definēts tā mērḳis. Likuma mērḳis ir jebkura likuma būtiska sastāvdaḷa, ko izmanto likuma normu interpretācijas gadỉjumā. 
Inga Eglitte, Osvalds Joksts. Galveno interešu centru noteikšanas un izvērtēšanas problemātika fizisko personu pārrobežu maksātnespējas procesos

Tā kā subjekta maksātnespēja skar gan kreditoru, gan arī paša parādnieka tiesības un pienākumus, likumdevējam ir skaidri jāpauž sava attieksme saistībā ar to, kā intereses kreditoru vai parādnieku - aizsargā attiecīgais maksātnespējas tiesiskais regulējums vai iespēju robežās - gan kreditoru, gan parādnieku. Pēdējo izdarìt ir visai grūti, jo kreditori grib saṇemt sava prasījuma apmierinājumu, savukārt parādnieks - atjaunot savu maksātspēju un atbrīvoties no atlikušajām parāda saistībām. Bieži sabiedrībā valda viedoklis, ka parādnieks ir sliktais, tādēl vin̦š būtu jāsoda. Taču patiesībā var izrādīties, ka sava atbildības daḷa būtu jāuzn,emas arī pašam kreditoram, kurš, aktīvi aicinot slēgt līgumu, nemaz nav vērtējis otras puses spēju izpildìt saistības [1].

Pēc valstiskās neatkarības atgūšanas laikā, kad Latvijā tikai veidojās tirgus ekonomika, aktuāla kḷuva vajadzība regulēt arī tirgus dalībnieku iespējamo maksātnespēju. 1992. gada 1. janvārī stājās spēkā samērā nepilnīgs likums "Par uzṇēmumu un uzṇēmējsabiedrību maksātnespēju un bankrotu", tāpēc valdība vairākus gadus strādāja pie jauna likuma sagatavošanas. 1995. gada 16. novembrī Ministru prezidents Māris Gailis izdeva rīkojumu Nr. 688 "Par darba grupu likumprojekta "Par maksātnespēju" izstrādei". Par darba grupas vadītāju iecēla Ekonomikas ministrijas valsts sekretāra vietas izpildītāju Juri Cebuli. Darba grupai deva uzdevumu lïdz 1995. gada 5. decembrim pabeigt likumprojekta "Par maksātnespēju" izstrādi un iesniegt to Ekonomikas ministrijai tā tālākai izskatīšanai Ministru kabinetā.

Likumprojekta izstrādes gaitā nomainīja likuma iespējamo nosaukumu, un 1996. gada 12. oktobrī spēkā stājās jauns likums "Par uzṇēmumu un uzṇēmējsabiedrību maksātnespēju”. Šajā likumā tāpat kā iepriekšējā maksātnespējas subjektu lokā netika iekḷautas fiziskās personas. Divdesmit pirmā gadsimta sākumā vairākkārt izskanēja doma par jauna regulējuma nepieciešamību, un vairāku gadu garumā tapa Maksātnespējas likums, kas stājās spēkā 2008. gada 1. janvārī. Tobrīd jaunā Maksātnespējas likuma izveides mērḳis bija novērst iepriekšèjā regulējuma nepilnības un trūkumus, pastiprinot kreditoru interešu aizsardzību. Kreditoru kopuma interešu istenošana praksē tika vērtēta kā prioritāra. Lỉdz ar to lielākā daḷa juridisko personu maksātnespējas procesu noslēdzās ar likvidācijas procedūru, tādā veidā nedodot iespēju finansiālās grūtībās nonākušajam komersantam veikt pasākumus maksātspējas atjaunošanai.

Tāpat tika uzskatīts, ka iepriekšējā maksātnespējas procesa regulējumā bija iekḷauts nepilnīgs maksātnespējas subjektu loks. Piemēram, tajā nebija iekḷautas fiziskās personas, biedrības, nodibinājumi, kapitāla un finanšu tirgus dalībnieki. Turpretim daudzās valstīs, tādās kā Vācija, ASV, Francija, Lielbritānija, Austrālija, Jaunzēlande, Nīderlande, Dānija, İrija, Somija, Zviedrija, Kanāda, Krievija, K̦ina, Japāna un citas, jau gadiem ilgi darbojās fiziskās personas maksātnespējas tiesību institūts.

Piemērojot Maksātnespējas likumu praksēè, vēl netika atrisināti visi neskaidrie ar maksātnespēju saistītie jautājumi, kad 2009. gada vidū atkal radās ideja par jauna Maksātnespējas likuma nepieciešamību. To veicināja ārvalstu kapitāla aizsardzības intereses un Starptautiskā Valūtas fonda palīdzība ekonomiskās krīzes pārvarēšanai. Pēc Tieslietu ministrijas pārstāvju tikšanās ar starptautisko aizdevēju pārstāvjiem tika 
Inga Eglitte, Osvalds Joksts. Galveno interešu centru noteikšanas un izvērtēšanas problemātika fizisko personu pārrobežu maksātnespējas procesos

pien̦emts likums, veicot virkni grozijjumu esošajā maksātnespējas tiesiskajā regulējumā. Grozijumu mērḳis bija nodrošināt pasākumu izpildi, kas iekḷauti Starptautiskajam Valūtas fondam adresētā Latvijas Republikas nodomu protokolā. Tā kā grozijumu apjoms bija ievērojams, idejas autori nolēma uzsākt darbu pie jauna likuma izstrādes.

Tika uzsvērta nepieciešamība novērst komercdarbības veicēju skaita krasu samazināšanos. Likuma izstrādes gaitā izskanēja arī brīdinājumi par to, ka ārvalstu banku akcionāri, iespējams, vēlēsies atgūt no valsts tiesas ceḷā zaudējumus, kas radīsies, ieviešot atvieglotu privātpersonu bankrota procedūru. Šādu brīdinājumu pamatā bija arguments par to, ka tādējādi tiekot pārkāpts tiesiskās paḷāvības princips. Šajā sakarā ir būtiski norādīt uz Satversmes tiesas pausto atziṇu par to, ka "tiesiskās pạ̦āvības princips neizslēdz valsts iespēju grozìt pastāvošo regulējumu. Pretēja pieeja novestu pie valsts nespējas reaǵêt uz mainīgajiem dzìves apstākḷiem”. Neapšaubāmi, ka tieši ekonomiskā krīze radīja nepieciešamību grozìt esošo regulējumu [1].

Kopš 2017. gada 26. jūnija gan tiesām, gan maksātnespējas procesā iesaistītajām personām un iestādēm maksātnespējas procesa gaitā ir pienākums piemērot Eiropas Parlamenta un Padomes 2015. gada 20. maija Regulas (ES) 2015/848 par maksātnespējas procedūrām noteikumus (turpmāk - Jaunā regula) [2]. Minētā regula ir tikusi pieñemta, aizstājot 2000. gada 29. maija Padomes Regulu (EK) Nr. 1346/2000 par maksātnespējas procedūrām (turpmāk - Vecā regula).

Palielinoties dalībvalstu savstarpējai integrācijai Eiropas Savienības (turpmāk ES) ietvaros, laika gaitā arvien pieaug to gadījumu skaits, kad vienā dalībvalstī notiekošs maksātnespējas process iegūst pārrobežu raksturu un rada pamatu Jaunās regulas normu piemērošanai tādēl, ka procesā kreditoru lomā ir iesaistītas personas no citām ES dalībvalstīm, parādnieka manta daḷēji atrodas citā dalïbvalstī u. tml. ${ }^{1}$ [3] Jaunās regulas tiesību normu piemērošana nav uzskatāma par retu parādību ne tiesās, ne arī maksātnespējas procesa administratora vai citu maksātnespējas tiesību piemērotāju darbā. Jaunā regula ir attiecināma gan uz fizisko, gan juridisko personu maksātnespējas procesiem [2] un ir uzskatāma par komplicētu un apjomīgu tiesību aktu, kura tiesību normu piemērošanas problemātika izraisa plašas diskusijas starp tiesību zinātniekiem un arī starp tiem, kas ar šo Jauno regulu strādā.

\section{Fiziskās personas maksātnespējas pieteikuma piekritības noteikšana caur galveno interešu centru}

Arvien biežāki ir gadījumi, kad Latvijā ierodas citu valstu pilsoṇi realizēt Latvijā fiziskās personas maksātnespējas procesu, kas Latvijā, salīdzinot ar citām ES dalībvalstīm, ir pieejamāks un arī procedūra ir vienkāršotāka. Jebkurš fiziskās personas maksātnespējas

1 Atbilstoši Eiropas Komisijas publicētajiem datiem laika periodā no 2009. līdz 2011. gadam vidēji 200000 uzṇēmumu gadā Eiropas Savienībā kḷuva maksātnespējīgi. Aptuveni viena ceturtdaḷa no minētajiem maksātnespējas procesiem ir bijuši ar pārrobežu elementu. 
Inga Eglitte, Osvalds Joksts. Galveno interešu centru noteikšanas un izvērtēšanas problemātika fizisko personu pārrobežu maksātnespējas procesos

process tiek uzsākts ar prasības pieteikuma sagatavošanu, pamatojoties uz informāciju, kāda fiziskai personai ir pieejama, un to, kāds ir pamatojums fiziskās personas maksātnespējas pasludināšanai.

Tā parasti prasības pieteikumā tiek aprakstīts fiziskās personas-parādnieka šā brīža mantiskais stāvoklis un tas, kāpēc viņš ir spiests iesniegt fiziskās personas maksātnespējas procesa pieteikumu, lūdzot tiesu pasludināt fiziskās personas maksātnespējas procesu. Tālāk tiek aprakstīti maksātnespējas faktiskie apstākḷi, kā arī mantiskais un gímenes stāvoklis. Latvijas Republikas Maksātnespējas likuma 129. pantā ir noteikts, ka parādniekam var piemērot fiziskās personas maksātnespējas procesu, ja personai nav spēju nokārtot parādsaistības, kurām iestājies termiņš, un parādsaistības kopā pārsniedz 5000,00 EUR. Tiesai un pirms tam arī pašam parādniekam ir jākonstatē parādu kopējais apmērs, kam ir jāpārsniedz likumā noteiktais slieksnis. Pēc tam var secināt, vai parādniekam ir iestājusies Maksātnespējas likuma 129. panta pirmās daḷas 1. punktā definētā pazīme [4].

Maksātnespējas likuma 127. pantā ir teikts, ka fiziskās personas maksātnespējas procesa subjekts var būt jebkura fiziskā persona, kura pēdējo sešu mēnešu laikā ir bijusi Latvijas Republikas nodokḷu maksātājs un kurai ir finansiālas grūtības. Tādējādi, iekḷaujot šo prasību, likumdevējs ir nostiprinājis priekšnoteikumu par fiziskās personas galveno interešu centra atrašanos Latvijā [5].

Papildus jau norādītajam un saskaṇā ar Civilprocesa likuma 363.22 panta pirmo daḷu fiziskās personas maksātnespējas procesa lietu atbilstoši parādnieka pieteikumam tiesa izskata pēc parādnieka deklarētās dzīvesvietas, kas parādniekam reğistrēta trīs mēnešus pirms pieteikuma iesniegšanas tiesā, bet, ja tādas nav, pēc tā dzīvesvietas. Arī šajā gadījumā te parādās normatīvo aktu definējuma interpretācijas piel̦aujamība, ko parādnieks var tulkot sev par labu. Latvijas Republikā ir piekritība uzsākt Jaunās regulas 3. panta 1. punktā noteikto maksātnespējas procedūru.

Civilprocesa likuma 363.22 panta otrā dạı nosaka, ka lietu par Jaunās regulas 3. panta 1. punktā noteiktās maksātnespējas procedūras uzsākšanu izskata tiesa pēc parādnieka galveno interešu centra atrašanās vietas, bet šĩs regulas 3. panta 2. punktā noteiktās maksātnespējas procedūras uzsākšanas gadījumā - pēc parādnieka saimnieciskās darbības (Jaunās regulas 2. panta 10. punkta izpratnē) atrašanās vietas. Ievērojot Maksātnespējas likumā un Jaunajā regulā minēto, rodas piel̦aujamība tiesību normu interpretēt savā labā, kas bieži vien tiek akceptēts, arī ar tiesas nolēmumu pasludinot Latvijā ārzemnieka-fiziskās personas maksātnespējas procedūru, kurš savu galveno interešu centru ir pielāgojis sev izdevīgākajā veidā.

Jaunās regulas preambula nosaka, ka šĩ regula l̦auj sākt galvenās maksātnespējas procedūras dalībvalstī, kurā ir parādnieka galveno interešu centrs. Šīm procedūrām ir vispārēja darbības joma, un to mērkis ir aptvert visus parādnieka aktīvus. Bet kādi tad pārsvarā parādniekam ir aktīvi? Kad tiek pieteikta fiziskās personas maksātnespēja, tie 95\% gadījumu ir tuvu minimālajai mēnešalgai bez nekustamās un kustamās mantas. Tad rodas iespējas un piel̦aujamība, ka fiziskā persona var dzīvot jebkurā vietā pasaulē, tādā veidā rodot iespēju noteikt savu galveno interešu centru valstī, kurā dzīvo. Te ir liela 
Inga Eglïte, Osvalds Joksts. Galveno interešu centru noteikšanas un izvērtēšanas problemātika fizisko personu pārrobežu maksātnespējas procesos

atšḳirība starp reālo un deklarēto dzìvesvietu, kur arī ir problēmas sakne, ko advancēti juridiskie biroji vai atsevišḳi juristi dažādos veidos mēgina piemērot savu klientu interesēs, vienlaikus pielaujot kḷūdu, tādā veidā maldinot gan klientu, gan arī pēc tam tiesu un parādnieka kreditorus.

Lai aizsargātu dažādas intereses, Jaunā regula l̦auj sākt sekundāro procedūru, kas notiktu līdztekus galvenajai procedūrai. Sekundāro procedūru var sākt tajā dalībvalstī, kurā atrodas parādnieka uzṇēmums. Sekundārās procedūras darbība attiecas tikai uz šajā dalībvalstī esošajiem aktīviem. Obligātas koordinācijas noteikumi galvenajā procedūrā atbilst vajadzībai pēc vienotības Eiropas Kopienā.

Jaunās regulas preambulas 40. punktā norādìts, ka sekundārā maksātnespējas procedūra papildus vietējo interešu aizsardzībai var kalpot dažādiem mērḳiem. Tā var notikt, ja maksātnespējīgā parādnieka manta ir pārāk sarežgíta, lai to pārvaldỉtu kā vienu veselu, vai arī ja attiecīgo tiesību sistēmu atšḳirības ir tik būtiskas, ka procedūras sākšanas dalībvalsts tiesību piemērošana var radīt sarežǵỉjumus citās dalībvalstīs, kurās atrodas aktīvi. Šajā nolūkā maksātnespējas procesa administrators galvenajā maksātnespējas procedūrā var prasīt sākt sekundāro maksātnespējas procedūru, ja tas ir nepieciešams maksātnespējīgā parādnieka mantas efektīvai pārvaldī̌̌anai.

Novērtējot iesniegtos pierādījumus, tiesas, pamatojoties uz pieteikumā norādīto informāciju, secina, kur ir pieteicēja galveno interešu centrs un vai tas ir Latvijā. Bieži vien tiesas vadās no daḷējās izvērtēšanas aspektiem. Tā, piemēram, atteikumu ierosināt fiziskās personas maksātnespēju Latvijā tiesas nolēmumā pastarpināti pamato ar to, ka Latvijā parādnieka galveno interešu centra nav, jo pieteicēja prasības pieteikumā uzrādīti pārsvarā, piemēram, Lietuvas kreditori vai Vācijas kreditori, kaut arī dzīvesvieta un deklarētā dzīvesvieta parādniekam ir Latvija, kā arī parādnieks ir uzrādījis Valsts sociālās apdrošināšanas aǵentūras izziṇu par ienākumu un nodokḷu nomaksu Latvijā un norādījis, ka dzìvesvietā atrodas visa parādniekam piederošā kustamā manta. Tad ir skaidri saprotams, ka šāds tiesas nolēmums neietver visu nepieciešamo izpēti par to, kā tiesa ir noteikusi galveno interešu centru parādniekam, jo tas ir jāizvērtē daudz paplašinātāk un dzị̣āk, lai arì tas, iespējams, prasītu ilgāku laiku un papildu informācijas pieprasījumu no pieteicēja, turklāt bieži vien pieteicējs vienlaikus piesaka tiesai par viṇam liegtajām LR Satversmē atrunātajām cilvēktiesībām būt vienlīdzīgam likuma un tiesas priekšà.

Pieredze liecina, ka papildus tam, kurā valstī atrodas kreditori, tiesai būtu jāvērtē, vai trešās personas var noskaidrot parādnieka galveno interešu centru, un īpaša uzmanība jāvelta kreditoriem un viņu priekšstatam par to, kur parādnieks pārvalda savas intereses. Tas var nozīmēt, ka galvenā interešu centra pārvietošanas gadījumā kreditori būtu laikus jāinformē par jauno atrašanās vietu, no kuras parādnieks veic savu darbību, kā tas paskaidrots Jaunās regulas 28. apsvērumā.

Viens no argumentiem uzskatīt, ka parādnieka galvenais interešu centrs ir Latvijā, ir tas, ka kreditori pazinnojumus par parādsaistību apmēru sūtìjuši uz parādnieka dzìvesvietas vai deklarētās dzīvesvietas adresi Latvijā, no kā varētu secināt, ka parādnieks ir 
Inga Eglitte, Osvalds Joksts. Galveno interešu centru noteikšanas un izvērtēšanas problemātika fizisko personu pārrobežu maksātnespējas procesos

informējis savus kreditorus par dzivesvietas maiṇu uz Latvijas Republiku, lïdz ar ko pirmškietami parādnieks izpildījis Jaunās regulas preambulas apsvēruma 28. punktā noteikto kritēriju.

Turklāt tiesai būtu jākonstatē, ka parādnieks Latvijā veic neatkarīgu darījumu darbību vai profesionālo darbību, studē klātienē vai strādā klātienē algotu darbu. Tas ir viens no komponentiem, kas varētu pierādìt, ka parādnieka galvenais interešu centrs ir Latvijas Republikā, kas varētu kalpot par pamatu Jaunās regulas 3. panta 1. punktā noteiktās maksātnespējas procedūras uzsākšanai.

Taču pastāv daudzas nianses, kuras tiesai iesniegtajā maksātnespējas pieteikumā parādnieks tī̌si vai netî̌̌i bieži vien nav norādīiis, tātad - informācijas trūkums. Piemēram, ir daudzi un dažādi citi veidi un apstākḷi, pēc kuriem var secināt: lai arī tiesa, pēc parādnieka sniegtās informācijas piemērojot Jaunajā regulā noteiktās prezumpcijas, ir izvērtējusi pierādijjumus pareizi, taču parādnieks tiesai nav norādījis visu informāciju par sevi, kā rezultātā tiesa, kaut rīkojusies pareizi, pieṇēmusi nepareizu lēmumu par parādnieka galvenā interešu centra atrašanos Latvijā.

\section{Tiesas nolēmumi, kuros galvenais interešu centrs tomēr nav pareizi izvērtēts}

Maksātnespējas jomas regulējums netika iekḷauts 1968. gada Briseles Konvencijā [6], kas vēsturiski ir bijis pirmais Eiropas līmen,a normatīvais akts starptautisko privāttiesību jomā. Tas neliecina par maksātnespējas regulējuma maznozīmīgumu ES vienotā tirgus kontekstā, bet gan tieši pretēji - tā nozīme kopējā tirgus izveidē un pilnveidošanā, maksātnespējas procesā iesaistìto personu un interešu loks, kā arī prasījumu dažādība un sarežǵỉjumi, kas saistīti ar šāda kompleksa regulējuma pieṇemšanu, ilgu laiku nel̦āva dalībvalstīm vienoties par saistošu regulējumu [7]. Arī šobrīd ES maksātnespējas regulējumam nav starptautiska ekvivalenta un pastāv globāla interese par tā jēdzienu interpretāciju dalībvalstu nacionālo tiesību un Eiropas Savienības Tiesas lìmenì [8].

2015. gada 1. marta rekomendācijās un vadlīnijās "Efektīva Eiropas Savienības tiesību aktu pārrobežu tiesiskās sadarbības jomās civillietās izstrāde, pārṇemšana, ieviešana un piemērošana (Latvijā, Ungārijā, Vācijā, Zviedrijā un Apvienotajā Karalistē)" [9], kas ir attiecināmas uz Vecās regulas normu piemērošanu un publicētas divus gadus pirms Jaunās regulas spēkā stāšanās, Latvijas tiesām tika veltīta kritika attiecībā uz pārāk vienkāršotu un nekritisku pieeju fizisko personu maksātnespējas procesa pieteikumu izskatīšanai. Secināts, ka tiesas parādniekam ar pārrobežu procesa elementu pazīmēm par pietiekamu pamatu maksātnespējas procesa pasludināšanai Latvijā atzīst faktu, ka parādnieks ir deklarējis savu dzīvesvietu Lat vijā un ir reǵistrējies kā nodokḷu maksātājs. Tādējādi tiesas šādos gadījumos pēc būtības nemaz nepiemēro Vecās regulas normas, aprobežojas ar Maksātnespējas likumā noteikto pazìmju un priekšnoteikumu piemērošanu, nevērtējot parādnieka galveno interešu centra atrašanās vietu. 
Inga Eglitte, Osvalds Joksts. Galveno interešu centru noteikšanas un izvērtēšanas problemātika fizisko personu pārrobežu maksātnespējas procesos

Tādẹḷ var izdarìt vairākus secinājumus, kas nepārprotami spēj norādìt uz to, ka fiziskās personas galvenais interešu centrs tomēr neatrodas Latvijā, ka lietas apstākḷi ir visdažādākie un ka ir vērtējami un apskatāmi pat visneiedomājamākie galvenā interešu centra noteikšanas aspekti.

- Kādas citas valsts tiesa neilgi pirms tam jau ir pasludinājusi parādnieka maksātnespējas procesu, kā arī kādas valsts, piemēram, Vācijas, advokāts iecels pagaidu maksātnespējas administratoru, lïdz ar to Latvijas tiesa nemaz nevarēja pieṇemt nolēmumu par parādnieka galvenā interešu centra atrašanos Latvijā un maksātnespējas procesa pasludināšanu. Tã vietā bija taisāms nolēmums par tiesvedības izbeigšanu vai pieteikuma atstāšanu bez izskatīšanas.

- Parādnieks kādā citā valstī ir liela uzñēmuma vienīgais îpašnieks un vadītājs. Šì uzñēmuma apgrozījums ir vairāki simti tūkstošu eiro, kas ir būtiskāk par parādnieka četru mēnešu darba attiecībām kā valdes loceklim citai personai piederošajā SIA, saṇemot 600 eiro atalgojumu.

- Ir pamats uzskatīt, ka parādnieka pastāvīgā dzīvesvieta ir, piemēram, Lietuva, par ko liecina parādnieka veiktā suṇa turēšanas nodevas apmaksa - 36 eiro. Tādēl var secināt, ka parādnieka patiesā dzìvesvieta ir, piemēram Viḷnā, kur viṇš dzīvo kopā ar savu suni, nevis kāda no deklarētajām dzīvesvietas adresēm Latvijā.

Šādā gadījumā trešajai personai vai arī kreditoram/-iem, ṇemot vērā iepriekš norādìto un pamatojoties uz Maksātnespējas likuma 150. panta pirmo dạ̣u, Jaunās regulas 5. pantu un Civilprocesa likuma 363.27 panta 43 dalıu, būtu jāsniedz tiesā blakus sūdzība, jālūdz atcelt Latvijas tiesas nolēmums par parādnieka galvenā interešu centra atrašanās vietu Latvijā un jālūdz konstatēt, ka parādnieka galvenā interešu centra atrašanās vieta ir kāda cita valsts, uz ko norāda apstākḷi un pierādāmi fakti, vienlaikus lūdzot arī izbeigt maksātnespējas procesu.

Jaunās regulas 4. panta 1. punkts paredz, ka tiesa, kurā iesniegts pieteikums sākt maksātnespējas procedūru, pēc savas iniciatīvas pārbauda, vai pieteikums ir šìs tiesas piekritībā saskañā ar 3. pantu. Analizējot minēto Jaunajā regulā, skaidrs ir tikai viens tiesai nav viennozīmīgas prakses par šāda veida gadījumiem ar negodprātīgiem parādniekiem, un vēl sliktāk ir vērtējams tas, ka šādu gadījumu veicinātāji lielākoties ir juristi, kas mēǵina interpretēt tiesību normas un nevadās pēc galvenā Maksātnespējas likuma un Jaunās regulas mērḳa.

\section{Secinājumi un priekšlikumi}

1. Galvenā interešu centra jēdziena pareizai izpratnei un pareizai noteikšanai ir būtiska nozīme, lai taisnīgā tiesas procesā izspriestu, kurām no fiziskām personām, kas iesniegušas tiesā prasības pieteikumu par maksātnespējas pasludināšanu, maksātnespējas process ir pasludināms Latvijā.

2. Fiziskās personas pastāvīgās dzīvesvietas konstatācijas fakts Latvijā nevar būt par pamatu galvenā interešu centra noteikšanai, respektīii, dzīvesvietas 
Inga Eglitte, Osvalds Joksts. Galveno interešu centru noteikšanas un izvērtēšanas problemātika fizisko personu pārrobežu maksātnespējas procesos

deklarēšana un reǵistrēšanās kā nodokḷu maksātājam, tālruṇa numura reǵistrēšana Latvijā, privāto un uzṇēmuma kontu atvēršana Latvijā, ārstēšanās un medicīnisko pakalpojumu saṇemšana Latvijā nav pietiekams pamats noteikt, ka galvenais interešu centrs ir Latvijā.

3. Tiesām nav viennozīmīgas taktikas, kā varētu nekḷūīigi konstatēt, ka parādnieka galvenais interešu centrs patiesi (nevis tikai fiktīvi vai škietami) ir Latvijā, kā to norāda pats parādnieks pieteikumā ar vēlmi fiziskās personas maksātnespējas procesu pasludināt Latvijā.

4. Latvijas tiesu praksē un juridiskajā literatūrā šobrīd aktuālais un noteicošais viedoklis par galvenā interešu centra noteikšanu Jaunās regulas izpratnē nav efektīvs un ir mazfunkcionējošs, kas nenodrošina metodiski vienotu pieeju galvenā interešu centra noteikšanā, tādā veidā radot jaunus precedentus tiesu nolēmumos.

5. Viens no risinājumiem galvenā interešu centra noteikšanā atbilstoši Jaunās regulas noteikumiem: tiesām būtu sistemātiski un secīgi jāpiemēro šìs regulas 3. pantā ietvertās normas, nevis jābalstās uz fragmentāru tiesību normu izrāvumu, nepilnīgu piemērošanu un izṇēmumu piel̦āvumu.

\section{Problems Associated with Identifying and Evaluating Main Interest Centres within the Context of Cross-Boarder Insolvency of Natural Persons}

\section{Abstract}

The authors analyse how it is possibile in different ways to assess and study where the debtor's main centre of interests is located and under what circumstances the opposite can be concluded. Compilation of misleading information by debtors, which may create a misleading impression of courts to determine the main centre of interest in Latvia, which allows a debtor - a natural person to go through the insolvency or a natural person under a more lenient procedure compared to the country where the debtor is true (GIC). Summarising these issues (GIC) will allow to identify and analyse the most common stumbling blocks in court decisions, and the need to introduce common practices in order not to create or at least reduce new precedents of similar nature.

Keywords: civil procedure, insolvency process, insolvency of a natural person, main centre of interest. 
Inga Eglīte, Osvalds Joksts. Galveno interešu centru noteikšanas un izvērtēšanas problemātika fizisko personu pārrobežu maksātnespējas procesos

\section{Avoti un literatūra}

\section{Tiesību akti}

1. Bērziņš, G. (2018). Fiziskas personas maksātnespējas process. Tiesu namu aǵentūra.

2. Eiropas Parlamenta un Padomes Regula (ES) 2015/848 par maksātnespējas procedūrām. Pieñemta 20.05.2015. [20.11.2019. red.].

3. European Commission. (12.12.2012.) Communication from the Commission to the European Parliament, the Council and The European Economic and Social Committee. A new approach to bussiness failure and insolvency. Strasburg, COM (2012)742final, p. 2. Iegüts no: https://eur-lex. europa.eu/legal-content/EN/TXT/PDF/?uri=CELEX:52012DC0742 [sk. 11.11.2020.].

4. Maksātnespējas likums: Latvijas Republikas likums: pieṇemts 26.07.2010. un stājies spēkā 01.11.2010. Latvijas Vēstnesis. 124, 06.08.2010.

5. Rīgas apgabaltiesas Civillietu tiesu kolēgijas 2016. gada 13. oktobra lēmums lietā Nr. CA-3760-16.

6. Konvencija par jurisdikciju un tiesas spriedumu izpildi civillietā. Parakstīta Briselē 27.09.1968. [19.11.2019. red.].

7. Van Calster, G. COMIng, and Here to Stay. The Review of the European Insolvency Regulation. P. 2, para 1.1.4. Iegūts no: https://papers.ssrn.com/sol3/papers.cfm?abstract_id=2637003 [sk. 11.11.2020.].

8. Ragan A. (2010). COMI strikes a discordant note. Emory Bankruptcy Developments Journal. 117-168. Citēts pēc: Van Calster, G. COMIng, and Here to Stay. The Review of the European Insolvency Regulation. P. 2, para 1.1.4. Iegūts no: https://papers.ssrn.com/sol3/papers. cfm?abstract_id=2637003 [sk. 11.11.2020.].

9. Kačevska, I., Rudevska, B., Buka, A., Dambergs, M., Fillers, A. (01.03.2015.). Efektīva Eiropas Savienības tiesību aktu pārrobežu tiesiskās sadarbības jomās civillietās izstrāde, pārṇemšana, ieviešana un piemērošana (Latvijā, Ungārijā, Vācijā, Zviedrijā un Apvienotajā Karalistē). Rekomendācijas un vadlīnijas. Iegūts no: http://www.at.gov.lv/files/uploads/files/6_Judikatura/ EST\%20judikatura/TM_vadlinijas_ES\%20parrobezu.pdf [sk. 11.11.2020.]

10. Padomes Regula (EK) Nr. 1346/2000 par maksātnespējas procedūrām. Iegūts no: https://eur-lex. europa.eu/legal-content/LV/TXT/HTML/?uri=CELEX:32000R1346\&from=LV 